\title{
SOCIAL CONTROL INSTEAD OF SOCIAL CHANGE: THE ADMINISTRATION OF LAND REFORM IN THE DOMINICAN REPUBLIC*
}

\author{
By Hans F. Illy
}

This paper does not intend to give a comprehensive picture of the Dominican Republic's efforts towards land/agrarian reform ${ }^{1}$. It focusses on two fields of interest: (1) What is the role played by the public administration system in the implementation of the reform programme? (2) Which are the political/social factors that have determined the relatively poor outcome of the reform effort?

To begin with the second point: It is intriguing to argue that political instability in Latin America can be explained by the high concentration of land ownership. Such a reality exists also in countries of other continents which, by no means, can be classified as "instable" 2 . But land reform has become one of the prominent political issues in Latin America, the bad conscience of ruling elites constantly being kept up by some well-meaning influence from outside: „Through the Alliance for Progress, agrarian reform is an objective that all Latin American nations are pledged to fulfill, sooner or later ${ }^{3}$." On the other hand, the mounting pressure from below, i.e. from the underprivileged peasantry, tends to jeopardize governments if this problem will not be solved 4 . Land reform is one means to attain more distributive justice in societies where the class cleavages are becoming intolerable ${ }^{5}$. A look at a thorough comparative study on the political implications of land reform all over the world suggests a basic hypothesis which, though rather sounding like a truism, also seems to be relevant for the context we are dealing with: "The manner in which the elite formulates a program and the content of the program it finally adopts are determined primarily by the relations between the elites and the landed class.". For analytical purposes, the author distinguishes between "cooperative" and "separated" elites to shed some light on the mechanisms, achievements and shortcomings of land reforms. As it is obvious that the Dominican Republic scene comes under the heading of "cooperative elites", the aspect which concerns us foremost is how the land reform doctrine is twisted and distorted into directions which suit those in power and those supporting the power-holders better. In such an environment, the perform-

\footnotetext{
* This paper was first presented to the European Consortium for Political Research Joint Sessions of Workshops, Berlin, March 27-April 2, 1977. It is part of the output of a research project on the Carit

1 Though such an effort would be highly welcome. In general, the literature on rural problems is very scarce indeed. The author has profited from the respective chapter in Howard J. Wiarda's monumental study "Dictatorship, Development and Disintegration. Politics and Social Change in the Dominican Republic" (Published on demand by Xerox University Microfilms), Ann Arbor 1975, pp. 1496-1563, which covers agrarian reform efforts up to the mid-sixties. See also Marlin D. Clausner, Rural Santo Domingo, Philadelphia 1973 , pp. $230-265$.

2 See Bruce M. Russett, Inequality and instability: The relation of land tenure to politics, World Politics, XVI (April 1964), pp. 442-54.

3 Robert J. Alexander, Agrarian Reform in Latin America, New York/London 1974, p. 2.

4 Thomas F. Carroll, Land Reform as an Explosive Force in Latin America, in: Rodolfo Stavenhager (ed.), Agrarian Problems and Peasant Movements in Latin America, Garden City, N.Y. 1970, pp. 101-137.

5 Dale L. Johnson, On oppressed classes, in: James D. Cockroft, André G. Frank, Dale L. Johnson (eds.), Dependence and Underdevelopment: Latin America's Political Economy, Garden City, N.Y. 1972,

6 Hung-Chao Tai, Land Reform and Politics, A comparative analysis, Berkely, Los Angeles, London 1974, p. 90 .
} 
ance of land reform will be necessarily limited, especially if one adopts the following definition: "... public programs that seek to restructure equitably and rationally a defective land-tenure system by compulsory, drastic and rapid means ${ }^{7}$." Those who advocate that land redistribution alone does not lead to cumulative changes in the rural sector unless it is combined with capital development (changes in land use, agricultural technology, credit, marketing) are right ${ }^{3}$, but this aspect is outside the focus of this paper.

The second field of interest in this paper, besides gauging the impact of political and social factors, is the involvement of the administrative apparatus (or bureaucracy) in the execution of the land reform programme. This may be defined "as a concrete organisation, composed of hierarchically related roles, serving formally as agent for a larger social entity or system.". To conceive of public administration as the docile instrument of political decision-makers, has never been valid, because "there is no reason to assume that state officials will willingly adopt and seek to implement norms set by others. Insofar as they exercise autonomous power, they set their own goals ${ }^{10}$." The departure from the ideal-type means-end separation of functions can go such far that observers, especially of post-colonial states in Asia and Africa, can arrive at the conclusion that these are "administrative states", where the bureaucracies enjoy quasi-unlimited power vis-à-vis the political actors ${ }^{11}$. Thus, it is indeed a scientific task of the first order to analyse the developmental capacity of the bureaucracy to handle the "crises" with which a politically developing country is confronted ${ }^{12}$. Is this model, predominant in the representative literature on the subject, applicable to Latin America? It seems appropriate to go back to the origins of the discipline in order to have a closer look at the other end of what can be called a continuum of the politics-bureaucracy relationship: There might also be found weak administrative systems much more dependent on the over-arching will of political decisionmakers ${ }^{13}$. In such circumstances, it will be difficult to demarcate what are exactly political and administrative functions. Being in symbiosis with political leaders, the bureaucracy's top officials might perform political roles ${ }^{14}$, and organisations, hitherto outside of the focus of administrative research, e.g. the military, might assure, or be assigned to, administrative roles ${ }^{15}$. Bearing this in mind, research on public administration in Latin America presents a special challenge. Unfortunately,

7 Ibid., p. 11.

8 Charles J. Erasmus, Agrarian vs. Land Reform: Three Latin-American countries, in: Philip K. Bock (ed.), Peasants in the Modern World, University of New Mexico Press, 1969 (pp. 9-31), p. 30; and Alexander, op. cit., pp. $2-3$ (he prefers "agrarian reform" to land reform, using "agricultural reform" in the wider sense of qualitative improvements).

9 Fred W. Riggs, Administrative Development: An elusive concept, in: John D. Montgomery and William J. Siffin (eds.), Approaches to Development: Politics, Administration and Change, New York, London, Sydney, Toronto 1966 (pp. 225-255), p. 227.

10 Ibid., p. 253.

11 E.g. Ralph Braibanti, Administrative Modernization, in: Myron Weiner (ed.), Modernization: The Dynamics of Growth, Voice of America Forum Lectures, 1966 (pp. 181-195), p. 183, in the same lign of argumentation: Joseph La Palombara, An Overview of Bureaucracy and Political Development, in: Idem (ed.), Bureaucracy and Political Development, Princeton, 21967 , (pp. 23-33), p. 23.

12 See a contribution standing in the tradition of the classical structural-functional model-building of the Committee on Comparative Politics of the Social Science Research Council: Joseph La Palombara, Public Administration and Political Change: A theoretical Overview, in: Charles Press and Alan Arian (eds.), Empathy and Ideology: Aspects of Administrative Innovation, Chicago 1966, pp. 72-107.

13 This alternative is still present in Alfred Diamants' analysis and hypotheses: Modellbetrachtung der Entwicklungsverwaltung, Baden-Baden 1967, p. 27.

14 John D. Montgomery. A Royal Invitation: Variations on three Classic Themes, in: Idem/W. J. Siffin (eds.), Approaches to Development (note 9), p. 272 (without hinting to Latin America).

15 Richard C. Rankin, The expanding institutional concerns of the Latin American military establishments: A review article, Latin American Research Review, Vol. IX, No. 1, 1974, pp. 81-108. 
the discipline is underdeveloped ${ }^{16}$, lagging behind other branches of political science. As a starting point in this web of theoretical considerations, it appears useful to verify the following statement: "The political environment of public administration has probably been neglected by those who emphasize what is apparently bureaucratic pathology in Latin American countries. In fact, public administrators cannot do much more than the polity allows ${ }^{17}$."

Let us now turn to the subject of land reform in the Dominican Republic. We shall proceed in the following stages:

(1) Some relevant data

(2) Origin and orientation of land reform

(3) The administrative set-up and process of land reform

(4) The socio-political determinants of land reform

\section{Some relevant data:}

The Dominican Republic comprises about 5 Million inhabitants on $48,442 \mathrm{~km}^{2}=$ 4, 844, 200 hectares. About $55 \%$ of this amount are of actual or potential agricultural use and thus included into the Agricultural Census. The land use pattern is presented in Table $1^{18}$.

Table 1 Land Use (in thousands of hectares)

\begin{tabular}{lrrrr}
\hline & \multicolumn{2}{c}{1960} & \multicolumn{2}{c}{1971} \\
& ha & \% & ha & \multicolumn{1}{c}{$\%$} \\
\hline Seasonal Crops & 280 & 12.4 & 292 & 10.9 \\
Permanent Crops & 452 & 20.0 & 533 & 20.1 \\
Fallow & 336 & 14.9 & 142 & 5.3 \\
Pasture & 887 & 38.4 & 1,432 & 53.7 \\
Forest & 286 & 12.7 & 250 & 9.4 \\
Other & 37 & 1.6 & 16 & 0.6 \\
\hline & 2,258 & 100.0 & 2,665 & 100.0 \\
\hline
\end{tabular}

These figures reveal a slight diminution $(-1.4 \%)$ of crop surfaces - a strange phenomenom if one considers the population increase of $3.0 \%$ per year ${ }^{19}-$ and a real boom in pastures. The latter result has to be kept in mind because, in some way, it has to do with the effects of land reform.

In 1972, the agricultural sector contributed $21.1 \%$ to the Gross National Product compared with $32.8 \%$ in $1960^{20}$, thus reflecting the industrial development of the country. Agriculture, for the same year, stands for $77.6 \%$ of the country's exports $^{21}$. As about $60 \%$ of the working population live in rural regions ${ }^{22}$, an

16 Jack W. Hopkins, Contemporary research on public administration and bureaucracies in Latin America, Ibid., pp. 109-139.

17 Alberto Guerrero-Ramos, The New Ignorance and the Future of Public Administration in Latin America, in: Clarence E. Thurber and Lawrence S. Graham (eds.), Development Administration in Latin America, Durham, N.C., 1973 (pp. 382-422), p. 420.

18 Taken from PLANDES 19, Bases para formular una política de empleo en la República Dominicana, Santo Domingo 1974 , p. 108

19 Ibid., p. XII.

20 Simposio Nacional sobre Política Tributaria como Instrumento para el Desarrollo, 1974, Doc. No. 9, p. 5 .

21 Ibid., p. 6

22 PLAN̉DES 19, p. 3. 
important portion of the country's development efforts should be directed towards this sector. One indicator of their living conditions is the distribution of farms according to their size (Table 2) ${ }^{23}$.

Table 2 Number and Size of Farms 1971

\begin{tabular}{lrrrr}
\hline $\begin{array}{l}\text { Range } \\
\text { in ha }\end{array}$ & $\begin{array}{c}\text { No. of } \\
\text { farms }\end{array}$ & \multicolumn{1}{c}{$\%$} & $\begin{array}{c}\text { Area } \\
\text { (thousand ha) }\end{array}$ & \multicolumn{1}{c}{$\%$} \\
\hline Total & 253,300 & 100.0 & $2,677.5$ & 100.0 \\
$0.5-5$ & 182,222 & 71.9 & 340.3 & 12.7 \\
$5-101$ & 67,995 & 26.9 & $1,146.7$ & 42.9 \\
$101-803$ & 2,658 & 1.0 & 511.7 & 19.1 \\
803 and more & 425 & 0.2 & 678.8 & 25.3 \\
\hline
\end{tabular}

Farms of less than 5 ha (nearly three quarters of the total) can be called "minifundios" and cover only one eighth of the cultivable land, whereas a very small minority of owners occupy one fourth of the land. This is indeed one of the most unequal patterns of land distribution on the globe ${ }^{24}$. But these figures alone cannot offer more than a rather superficial description of the actual reality, because they exclude an important part of rural conditions, namely those who are longing for some land where to live, work and survive. Nevertheless, some more rough figures are self-explanatory: Only $53 \%$ of the minifundistas cultivate their own land, $11,2 \%$ are leaseholders (called "arrendatario", if he pays rent in cash, "aparcero" if he pays with part of the crop), 27,9\% occupy lands without holding a legal title, $8 \%$ "other forms" of possession ${ }^{25}$.

This reflects instability, very low income ${ }^{26}$, dependence on the bigger landowners, for whom a high percentage of the sub-employed smallholders are obliged to work. If one adds a minimum of 100,000 landless agricultural labourers ${ }^{27}$ who certainly do not regularly enjoy the legal minimum daily pay of 2.50 Pesos $^{28}$ (= US \$), one arrives at the conclusion that nearly half of the Dominican population are concentrated in the rural hinterland where they live at a level of bare subsistence if not partly in sheer misery ${ }^{29}$. Indeed, estimates as to how many peasants should be included into a comprehensive land reform programme run up to 350,000 family heads ${ }^{30}$ (family size 6-10). At the other end of the scale, there are to be found the large land holdings, not quite a terra incognita as the puzzling multitude of minifundios but, for political reasons, largely outside of the statistics and, as we shall see, shielded from the agrarian reform. This group can be subdivided into the following holders: 111,000 ha owned by the American corporation Gulf and Western ${ }^{31}$ (planted half with sugar cane, half with pasture);

23 Sexto Censo Nacional Agropecuario 1971, Boletin XIV, Febrero 1973.

24 The Dominican Republic ranks 12 th as to its Gini index among 54 countries covered in: Charles L. Taylor and Michael C. Hudson, World Handbook of Political and Social Indicators, New Haven and London, 21975 , p. 267.

25 Sexto Censo Nacional Agropecuario.

26 Figures are extremely unreliable, a monthly average of $\$ 30$ for the lowest stratum will convey an idea (Secretaría de Estado de Agricultura, Diagnóstico y Estrategia del Desarrollo Agropecuario 1976-1986, Santo Domingo 1975, p. 5).

27 PLANDES 19 , p. 98.

28 Diagnóstico y Estrategia ..., p. 7.

29 See the illustrative article by Carlos M. Campos and Alberto Arredondo, Las condiciones de vida del campesino dominicano, Panoramas, No. 4. 1963 , pp. 81-110.

30 From a paper "Diagnóstico institucional de la reforma agraria en la República Dominicana", s. d., p. 43 ; see also El Nacional, March 29,1976, p. 7.

31 José del Castillo et al., La Gulf + Western en República Dominicana, Santo Domingo 1974, p. 129. 
232,000 ha of state-owned sugar land ${ }^{32}$; a larger part of the rest goes to the third sugar producer, the Dominican family of Vicini. Sugar is the backbone of the country's export economy, its proceeds serve as grease to keep running the government's machinery or, from a more critical point of view, the sugar industry is the stumbling-block for a more dynamic orientation of Dominican economy and society ${ }^{33}$.

\section{Origin and orientation of land reform:}

The crucial turning point in Dominican politics is the year 1961, when the 31 years long dictatorship of Rafael Trujillo ended. He had transformed the country into his private kingdom, accumulating more and more of the country's wealth, both land and business firms. Thus, it is estimated that in 1961 at least 11.6 million tareas $^{34}$ of land were to be considered state lands $(=730.000 \mathrm{ha})$, roughly one third of the total arable surface (see Table 1$)^{35}$. Theoretically speaking, half of this would be apt for settlement of 48,000 families in parcels of 120 tareas each ${ }^{36}$. However, mention should be made of the fact that by 1960, Trujillo had created 39 colonies, encompassing 12,290 families and about 2 million tareas ${ }^{37}$. But he did that with obvious strategic purposes: "The oldest and most persistent motivation for the establishment of colonies has stemmed from the traditional fear of Haiti's burgeoning population and the need to bolster the thinly-populated frontier against infiltration... In retrospect, government supervision of the colonies has been detailed and regulations have been strictly enforced ... the resulting regimentation may appear excessive ${ }^{38}$." There is no reason to believe that those colonies along the Haitian border contributed to the economic and social development of the "región fronteriza". This is still the most miserable part of the country ${ }^{39}$. At any rate, to outdo Trujillo by distributing state lands alone, seemed to be, in 1961, a rather easy task for a "democratic" regime. Of course, to call this measure an agrarian reform would sound rather big talk. As there was great public pressure to initiate a land reform programme, the Council of State took some action and distributed land that had belonged to a brother of Trujillo to some fifty families. But this was done more as a gesture to gain political legitimacy than a well-planned and executed programme ${ }^{40}$.

An important landmark in land reform, however, was Law No. 5879 of April 27, 1962, which established a specialized agency, the "Instituto Agrario Dominicano" to carry out "Reforma Agraria". But unfortunately, this law did not contain a

\footnotetext{
32 PLANDES 19, p. 97.

33 And, this may be added, a constant source of bickering with the Haitian government, because the industry relies upon 40,000-60,000 seasonal cane-cutters from the still much poorer part of Hispaniola.

34 The national square measure; 15.9 tareas equal one hectare, 6.4 make one acre.

$35 \mathrm{It}$ is true that this fact has some historical roots: As early as $1871,1 / 4$ to $1 / 3$ of land belonged to the state, especially due to the confiscation of church lands under the Haitian occupation (1822-1844) and the incorporation of properties of unlucky political adversaries (see Harry Hoetink, El Pueblo Dominicano 1850-1900, Apuntes para su Sociología Histórica, Santiago de los Caballeros 1971, p. 18).

36 Peter Dorner et al., Agarian Reform in the Dominican Republic. The views of four Consultants, University of Wisconsin, Madison 1967, p. 29.

37 John T. Westbrook, Socio-economic factors related to success and failure in agrarian reform: The "Caracol" project, República Dominicana, in: F. M. Andic and T. G. Mathews (eds.), The Caribbean in Transition, Rio Piedras 1965 (pp. 293-325), p. 293; and Dorner, op. cit., p. 30.

38 John P. Augelli, Agricultural colonization in the Dominican Republic, Economic Geography, Vol. 38, No. 1, 1962 (pp. 15-27), pp. 15, 17 and 20.

39 Suffice it to have a glance at the series of articles published in El Nacional, an afternoon daily, in the summer of 1975.

40 Howard J. Wiarda, The Dominican Republic, Nation in Transition, London 1969, p. 205.
} 
clear statement of goals and purposes, i.e. a platform for action. As one observer put it: "I must admit to having encountered difficulty in locating any definite statement which indicated the underlying philosophy of the reform movement in the Republic 41 ." In a general sense, the IAD was authorized to distribute two kinds of land, state and private. But there was no definition of what lands could be expropriated: "... as the law now stands, all privately owned rural property is potentially subject to expropriation, without distinction as to size, extent, and efficiency of production, labor arrangements, social conditions of the area etc. ${ }^{42}$." As a matter of fact, such a vague threat could only encounter resistance from the landed interests in society and, an important point for a country looking into a better future, could not be apt to spur up agricultural production. Under these circumstances, it is not astonishing, and indeed reasonable, that the land reform actions limited themselves to distribute state-owned land. But even this was, and still is, no easy task because there was a crucial lack of information on the exact amount and location of this land, the extent to which it had already been occupied, and the kinds of title or property rights held by government or by individuals. To launch the necessary field survey procedures, to initiate some reconnaissance and classification of soils, to determine their use for agriculture or cattle breeding, all this was still to be done. Of course, it could not be done in a short span of time, and people were waiting to get some "pedacito de tierra", a basic and legitimate aspiration of campesinos, aparceros, arrendatarios and labriegos (agricultural workers). American advisors, in retrospect, appear quite helpless after having assessed a situation which was more assimilated to a puzzle hiding the rules of its operation than a chessboard of registered titles to subdivide or to assemble (in the case of minifundios). On the one hand, they were quite conscious of the fact that an integral transfer of state lands would engender grave political consequences ("much of the land is under control of powerful landowners, many of them military men"), on the other hand they harboured the hope that land reform could be combined with the introduction of some land tax (which does not exist by 1977) ${ }^{43}$.

More vigorous action could be expected from Juan Bosch's government full of humanistic ideals of democracy and social justice which came to power by free elections in February 1963. He wanted to mobilize peasants and workers but thereby he frightened the established oligarchy, both civil and military. Only seven months later, his government was overthrown in a coup staged by the armed forces throwing the country into a civil war, intervention from outside and degenerating, since 1966, into a political regime sui generis represented by president Balaguer who had already pursued a career under Trujillo.

Bosch was not given a chance to put into practice what he considered a social revolution by a thorough land reform ${ }^{44}$. During his election campaign, Balaguer did his utmost to mobilize the rural masses and severely criticized the poor achievements of land reform. He promised a reform which was to liberate the peasants and to elevate them from their actual level of social inferiority to a respected factor in the Nation's life: "We shall only then have a real agrarian

41 Westbrook, op. cit., p. 294.

42 Thome in: Dorner et al., op. cit., p. 41.

43 I am referring to the Dorner et al. report, a good example to show how technicians handle a complex political reality (esp. pp. 4 and 17/18).

44 Wiarda, op. cit., p. 206. 
reform when our peasant is no longer simple flesh for exploitation but has transformed himself into a dynamic element in the process of our social rehabilitation and economic development ${ }^{45}$." In all of his later declarations, he felt committed to this vow ${ }^{46}$, and there is no reason to believe that this is pure political propaganda. But he has never been in a position to persuade all relevant sources of power in the social and political system to unconditionally back him in this effort, and much of the complexities of Dominican land reform implementation is due to this $\mathrm{fact}^{47}$. Nevertheless, Balaguer achieved more than his predecessors though, in 1969, one of the best-informed observers arrived at the conclusion that "the agrarian reform program conducted in the Dominican Republic in the past-Trujillo years has only begun to scratch the surface of some vast, underlying problems ${ }^{48}$." A new impetus was given when Balaguer pushed through the Congress his "Código Agrario", a whole bundle of laws destined to differentiate and to substantiate his far-reaching vision of land reform. This was in 1972, and since that date, there is much more struggle, and the antagonizing forces are getting more intelligible contours.

Before presenting a detailed analysis not so much of the contents of these laws but of their range of implementation, it is appropriate to give a list of projects (asentarnientos) realized by the Agrarian Reform Institute from 1962-1975 (Table 3) ${ }^{49}$.

Table 3 IAD Settlement Projects

\begin{tabular}{lccc}
\hline Year & Number & Beneficiaries & Area (tareas) \\
1962 & 4 & 883 & 59,523 \\
1963 & 12 & 703 & 74,658 \\
1964 & 8 & 1,607 & 162,879 \\
1965 & - & - & - \\
1966 & 7 & 300 & 31,915 \\
1967 & 21 & 1,099 & 161,365 \\
1963 & 18 & 1,518 & 116,307 \\
1969 & 24 & 2,132 & 193,948 \\
1970 & 21 & 1,033 & 63,236 \\
1971 & 15 & 3,615 & 376,070 \\
1972 & 32 & 5,812 & 541,607 \\
1973 & 92 & 8,313 & 640,716 \\
1974 & 18 & 1,800 & 143,813 \\
\hline Total & 272 & 28,815 & $2,566,037$ \\
\hline
\end{tabular}

This is less than $10 \%$ of those in need of land and constitutes only $6.7 \%$ of the country's arable land. This might be called a relative failure or a relative success according to the observer's point of view. At any rate, the total of land distributed

45 Speech at San José de los Llanos, January 22, 1966, in: Joaquîn Balaguer, La Marcha hacia el Capitolio, Santo Domingo 1973, p. 64

46 See "JB reitera el concepto la tierra debe ser para quien la trabaja", in: El Caribe, May 15, 1976, p. 22.

47 There is very much discussion on the land reform issue in the national press, though ideologically tinged and offering no reliable and complete picture. To my opinion, one of the best contributions is Mario Alvarez, La Reforma Agraria, published in El Caribe in four consecutive portions, March 6-9, 1976.

48 Wiarda, op. cit., p. 210

49 From: Diagnóstico Institucional de la Reforma Agraria, p. 42; figures for 1975 from El Caribe, May 4, 1976: 2,044 beneficiaries on 158, 139 tareas (number of projects unavailable). 
does only slightly supersede Trujillo's colonization achievements. But these figures alone do not tell the story fully. We have to examine the operational ramifications of the land reform programme and the administrative apparatus instituted to implement it.

\section{The administrative set-up and process of land reform}

The main instrument to realize the agrarian reform is the IAD (Instituto Agrario Dominicano) established in 1962. It is an autonomous entity ("organismo descentralizado" in the Dominican administrative nomenclature), formally linked to the Ministry of Agriculture, but virtually independent from it. Its policy is determined (according to official documents ${ }^{51}$ ) by a "directorate" composed of 9 members (4 ministers, the director of the Agricultural Bank, the director of the Industrial Development Corporation, and three more members appointed by the president). But official handbooks and statistics do not reflect the actual reality. IAD policy, if there is any, is determined by and dependent upon the direct relationship between the President and the IAD's Director General. The latter has to inform Balaguer regularly on the current activities of the institution and to ask for more funds if new projects are to be conceived. At the beginning of the fiscal year, all departments and decentralized entities are assigned their recurrent expenditure, i.e. essentially personnel costs. For the rest, ministers etc. have to go various times per year to the "Palacio" to ask for funds to become able to realize their programmes. The president disposes of what is called "Fondos Especiales", and he gracefully signes a cheque even for relatively petty sums (it is estimated that Balaguer personally authorizes more than half of the state's expenditure). But his preferences can change during the year as he is responsive to new priorities, insinuations as well as expert advice. He does that, surely, on the basis of a firm conviction that only he himself can prevent the waste of public funds. Thus, he is quite able to shape public action according to his vision which is directed primarily towards ostentatious investments like large avenues and places, urban housing projects and, to a lesser extent, rural settlement projects. Theoretically, this could offer a special, though patriarchical, impetus to agrarian reform. On the other hand, national planning is impossible in such an atmosphere of presidential grace and disgrace, and one is amazed to find a target figure of 10,000 families to settle in 1975 as well as in $1976^{52}$. This must be a pure invention of some minor officer in the budget office, and nobody cares about it.

If agrarian reform is considered a national enterprise of high priority, one should expect that relatively more funds and more personnel are allocated to the IAD. It does not seem that this is the case. The permanent personnel amounts to 859 which is about half of the Ministry of Agriculture's payroll, but less than that of comparable institutions like the Agricultural Credit Bank (970). A look at the

\footnotetext{
50 On a continental level, however, they show clearly that the Dominican Republic is to be classified amongst the less comprehensive land reforms. See: James W. Wilkie, Measuring Land Reform, Supplement to the Statistical Abstract of Latin America, UCLA Latin American Center, Los Angeles

51 Oficina Nacional de Administración y Personal, Manual de Organización del Gobierno, Santo Domingo 1972.

52 Oficina Nacional del Presupuesto, Presupuesto de Ingresos y Gastos de Instituciones Descentralizadas y Autónomas 1976, p. D-21-3.
} 
hierarchical composition reveals that only 77 earn more than $300 \$$ per month (Banco Agrícola 223). On the assumption that agrarian reform is a full-time job implying travelling to and staying some time in the regions, this has to be considered a miserable salary (civil servants in the capital's offices only work up to six hours per day and exercise a second job in the afternoon and early evening). Consequently, there is much fluctuation amongst the IAD personnel and a constant get-away to the private sector, especially the import-export trade. In all probability, the actual number of personnel must be considerably higher, about 1,20053 , because there is an additional source of financing, the so-called "fondos de contrapartida": when organizations like US-AID or the Interamerican Development Bank gave money to finance agrarian reform projects, they asked the Dominican government to give a special supplementary contribution to these funds. This was conceded by Balaguer, often more reluctantly than willingly, and more personnel could be recruited on this basis. That their situation was indeed very precarious became evident in April 1976 when Balaguer decided to withdraw these contributions which automatically implied the dismissal of these person $s^{55}$. He even blamed the respective institutions' heads for having blown up their personnel instead of dedicating these additional funds to the physical implementation of projects ${ }^{56}$. The fact that this measure was to hit four rural development oriented bodies equally (Ministry of Agriculture, IAD, Oficina de Desarrollo de la Comunidad, Instituto de Desarrollo y Crédito Cooperativo), shows that IAD and agrarian reform were not accorded, in the perception of the president and his advisors, a special place. Interviews with IAD officers revealed that the annual sum for capital investments, i.e. creation and maintenance of projects, about 5 million Pesos (= US $\$)^{57}$ for now about 300 projects $(16,700 \$$ per project), is largely insufficient to comply with the constant pressure exercised on the IAD to rapidly expand its activities ${ }^{58}$.

On the whole, the Instituto Agrario Dominicano is representative of the Dominican administrative system: no established recruitment patterns (e.g. no competitive entrance examinations), no civil service law, more emphasis on personal loyalty than on ability and competence. It might sound harsh to speak of "widespread nepotism, corruption, politically determined appointments and removals, lethargy, lack of professionalism, and inefficiency" 59 as almost accepted norms, but the Dominican Republic certainly presents one of the most traditional administrative systems of Latin America ${ }^{60}$. Though this does not mean that there is complete chaos - the rules of the game have their inner consistency - it would be audacious to infer some general autonomy of the administrative sector from the political decision-makers. Administrators are just not given the means to set their own goals. Cross-cutting loyalties and personal relations in a blown-up apparatus of 87,000 people $^{61}$ do not allow the enforcement of the rules of rational admini-

\footnotetext{
53 Ibid., p. D-21-5.

54 Diagnóstico Institucional de la Reforma Agraria, op. cit., p. 38 (plus 800 seasonal workers).

55 See Ultima Hora, April 13, 1976, p. 2; El Sol, April 14, 1976.

56 El Nacional, April 14, 1976, p. 10: Incertidumbre reina en empleados serán cancelados en Departamentos.

57 Diagnóstico Institucional, p, 48.

58 Interview with an agronomist, April 5, 1976.

59 Wiarda, op. cit., (note 40), p. 173 .

$60 \mathrm{~A}$ more detailed appreciation will be presented in a forthcoming study on development politics and public administration in the Caribbean.

61 According to the Presupuesto de Ingresos y Ley de Gastos Públicos 1976, p. 32.
} 
stration: "For the most part, the picture is one of lethargy, long coffee breaks, a great deal of talking and banter..."62. Of course, there is now cropping up some conflict with young technocrats ${ }^{63}$ in fields like economic planning ${ }^{64}$, personnel training ${ }^{65}$ and tax administration ${ }^{66}$, but these people are highly frustrated and marginalized, and look for the next available loop-hole to quit the service. It is only logical that the agrarian reform is intentionally kept out of the official planning documents ${ }^{67}$ which are, in any case, not considered an instrument to nourish political decisions.

Looking at IAD projects, it is difficult to pass a definite judgement because they are so different in quality. There are some which were never revisited by IAD technicians after the settlement of "parceleros"63. In other cases, the provisional titles were distributed (probably, in a solemn act presided over by the President himself), but problems arise as to the actual assignment of plots either because there are more titles than plots available in the project or because IAD employees were too negligent in implementing ${ }^{6}{ }^{69}$. Many of the first asentamientos have a particularly poor outlook. This is especially true for the three former Trujillo farms, Fundación, Madre Vieja y Canasta in San Cristóbal70 (10 Miles from Santo Domingo, 4,400 ha) where people live on a pure hand-to-mouth level instead of producing vegetables for the nearby capital's market. This situation can be phrased "a family has exchanged one form of bare subsistance life for another which may, in the final analysis, be even less satisfactory than that which they had before"71. In these projects, only 15-20 per cent of those settled in 1962 are still present. Many have sold their plots, even to military men who built nice weekend homes. Speculators puchased adjacent agrarian reform plots and thus aggregated up to 1,500 tareas $^{72}$. Though these practices were already forbidden in Law 5879 of 1962 in its article 39, a new law was passed laying down specific sanctions $^{73}$. One cause of this fluctuation was certainly the fact that when the settlers for the first projects were selected, the main criterion was not a reasonable experience in agriculture, but the social need (advanced age, large family). Under these circumstances, a good number of projects were doomed to failure ${ }^{74}$, i.e. the plot could not even feed a family, not to think of a marketable surplus.

62 Wiarda, op. cit., p. 169.

63 See some perceptive remarks on this problem in: A. E. Solari, R. Franco, J. Jutkowitz, Teoria, acción social y desarrollo en América Latina, Mexico 1976, pp. 283-300.

64 The Oficina Nacional de Planificación, part of the Secretariado Técnico de la Presidencia, produces well-made documents essentially for the shelves of public offices and foreign libraries.

65 The Oficina Nacional de Administración y Personal (same affiliation) does not recruit personnel and administer the respective records. A UNDP training project for civil servants 1972-74 did its best to change existing structures but failed.

66 To a symposium on tax reform in June 1974, organized on the instigation of the Organization of American States, the top economists of the country presented highly critical papers on the administrative shortcomings. But how to conceive a transformative strategy?

67 The Plataforma para el Desarrollo Económico y Social de la República Dominicana (1968-1985), Santo Domingo 1968, just offers some general remarks on the deficient land tenure structure (pp. 124) 25); The Plan Nacional de Desarrollo Agropecuario reproduces extensively in its Vol. II, Tomo 1 Aspectos Institucionales y Financieros de las Instituciones Ejecutoras, Nov. 1971, IAD laws and regulations, but does not give any information on doctrine, policy and projections.

68 See Mario Cáceres, Reforma Agraria, Historia, Logros y Fracasos, 2nd part, Listín Diario, March 18 1975 (citing the former "Finca de la Fanilia Cáceres").

69 Three articles in El Nacional give evidence of this anomaly: Febr. 2, 1974: Niegan entrega predios; June 3, 1974: Dan títulos pero no tierras a labriegos; June 18, 1974: No entregan tierras Nisibón a los poseedores de títulos.

70 Visit and talks with parceleros on July 7, 1975.

71 Westbrook, op cit, (note 37), p. 306

72 Listín Diario, Oct. 11, 1974: Votan prohibir venta parcelas.

73 El Caribe Sept. 11, 1974: Someten proyecto prohibe comprar parcelas reforma; Listín Diario, Nov. 5, 1974: Es ley proyecto prohibe venta parcelas reforma.

74 This is the result of Westbrook's analysis, op. cit. 
The influence of local politicians also played heavily, so that considerations of economic viability could not always prevail75. Nonetheless, that in one project (La Estrella, Villa Mella, near Santo Domingo) only 20 out of 60 settlers are said to be former agricultural labourers appears to be an extreme case. We were assured that things have changed drastically and that in more recently launched projects, people have more practical experience and are ethnically more homogeneous, i.e. they are not transferred from their region of origin to a completely distinct environment. Mention should also be made of the showcase projects of agrarian reform. These are "El Sisal" in the arid southern province of Azua where Israeli technical assistance has produced a well planned complex of 331 individual plots $^{76}$. Another very special case is Limón del Yuna, an immense rice farm with 1,600 settlers, the largest IAD project. This in itself is worth a special study because it shows how far the intervention of "el Poder Ejecutivo" (the abstract designation of the President) can go: Balaguer paid a visit to the project on October 9, 1974; obviously, he was not quite satisfied with what he saw so that, on the spot, he "ordered a better drainage system and disposed that pairs of oxen be given to the farmers"77 (Balaguer is a lawyer and a man of letters, not an agronomist!). A fortnight later, he placed the project under his personal control, quite an extraordinary measure even in the Dominican Republic ${ }^{78}$. This practically meant, according to a source within the IAD, that 100 instead of 15 tractors were moved to Limón del Yuna and more and better fertilizers were provided. A good example of how problems are solved in individual cases to the detriment of others. This asentamiento became again a subject of public discussion one year later when its transformation into a "collective project" was announced. This organizational form is based on Law No. 391 of 1972 following Law No. 290 (same year) which disposed the transfer of all rice farms into the hands of the state to centralize the production of this cereal predominant in the country's diet (64 IAD projects are collective rice farms ${ }^{79}$ ). It means that there is only collective property and that the "association of settlers" is not allowed to apply rules similar to those of a cooperative, but that practically everything is dictated by state officials ${ }^{80}$. Settlers cannot make a choice - in Limón del Yuna they were openly against collectivization ${ }^{81}$ - they have to give in or leave. The government's central argument is that the profits from collective farms are much higher ${ }^{82}$, and indeed they are in most cases. These collective projects are perhaps the purest expression of what an authoritarian system understands by agrarian reform: not the self-determination of individuals is the main objective, but the prolongation of dependence, this time not from "terratenientes" but from the state. Of course, in the tradition of the country's political culture, after the sale of the crop, the President personally passes cheques on to the settlers in a special ceremony as if these were gifts from a graceful monarch and not the legitimate price of their hard work.

\footnotetext{
75 Ibid., p. 297.

76 See Economía Dominicana, No. 27, 1971, pp. 37-42: Proyecto agrario “El Sisal”, Inauguración segunda etapa.

77 El Caribe, Oct. 10, 1974, p. 8: Jefe de Estado inspecciona obras realiza el Gobierno

78 The respective decree was published in the press (Listín Diario, Oct. 25, 1974).

79 Diagnóstico Institucional de la Reforma Agraria, p. 68

80 A close examination of the following document does not allow a more positive conclusion: Normas provisionales para la organización y funcionamiento de los asientamientos colectivos del Instituto Agrario Dominicano, s. d.

81 Listín Diario, Sept. 22, 1975: Afirma parceleros reciben mal trato; La Noticia, Sept. 21, 1975: PRSC (= the Christian Democratic Party) dice quieren incorporar a la fuerza parceleros proyecto

82 El Nacional, Sept. 18, 1975: Secretario considera como positivo colectivización provectos arroceros
} 
Another aspect of dependence, applicable to every kind of agrarian reform project, is the provision that settlers are not given definite titles, but only provisional ones (for 20 years) to be converted into a full title provided the settler pays for the parcel ( $25 \$$ per year) over this period ${ }^{83}$. This clause could not be enforced because of the host of irregularities already alluded to, but it definetely caused an atmosphere of fearful insecurity among the settlers who do not venture to complain about things they are not satisfied with lest they loose their plots.

Whereas the Instituto Agrario Dominicano is the central agency to implement the agrarian reform programme, it has no authority to take possession of the land it may intend to distribute. This is the task of a special body, the "Comisión para la Aplicación de las Leyes Agrarias", established in 1973 by decree No. 4168 (before that date, there existed four different commissions according to the different procedures to obtain land). The work of this body is rather controversial because from the start it has become evident that its work is tinted with much political haggling if not at times arbitrariness. Of course, Balaguer in person appoints the commission's nine members who are all conferred the prestigious title of "Secretario de Estado" (minister). The general opinion in the country is that as Balaguer has only appointed generals, politicians (of his party, the Partido Reformista) and great landowners to this body, there is not much to be expected from it ${ }^{84}$. These persons perform the delicate task to bargain with "terratenientes" to persuade them to cede part of their holdings to the state, but never in an act of expropriation because this could create political enemies. These arrangements are inconceivable without some adequate compensation (see below). There has always been much discussion about the blatant inefficiency of the commission to the extent that even the complete stop of its activities seemed to be imminent ${ }^{85}$. This did not come about due to the fact that the peasants wing within the governing Partido Reformista, the "Movimiento 'Agrario Reformista", voiced its criticism at various instances and even accused some members of the commission of laziness and infamous negligence of their duties ${ }^{86}$. It is indeed instructive to learn that people were summoned to the commission's offices in the capital and nobody was present to attend them ${ }^{87}$. Moreover, there is some foundation for the widely spread allegation that the commission can be very selective in its activities: the former vicepresident of the republic and now president of a minute opposition pary, the Movimiento de Integración Democrática (MIDA), Francisco Augusto Lora, was accused to occupy state-owned land. This was obviously a very unfair treatment because Lora could prove that he possessed a proper titles8. When cornered by all sorts of criticism, the commission itself quite frankly admits that the main stumbling-block for its action are the great landowners who constantly invent ways and means to evade the laws ${ }^{89}$.

In order to gauge the performance of the commission, it is appropriate to examine, law by law, to what extent these legal measures have been implemented to obtain as much land as possible for the land reform programme:

\footnotetext{
83 See Dorner et al., pp. $35 / 36$.

84 Diagnóstico Institucional de la Reforma Agraria, op. cit., p. 5.

85 El Nacional, Dec. 16, 1973: Podrían parar aplicación de las leyes agrarias.

86 El Nacional, June 7, 1976: Dice que cobran y no trabajan miembros comisión leyes agro.

87 El Nacional, June 9, 1976: Dice testimonio campesinos respalda denuncia comisión agro no trabaja.

88 Listín Diario, Nov. 25, 1974: Niegan Lora ocupe tierras del Estado; and Nov. 29, 1974: Lora reitera no aceptará citación hace comisión.

89 Listín Diario, Febr. 10, 1976: Dice entorpecen labor aplicación leyes agrarias.
} 
a) Law No. 292 which stipulates that state land should be passed back within three months (developed land up to 2,000 tareas used for cattle raising can be exempted under certain conditions): up to 1975 , only $19,4 \%$ of formally state-owned land could be recovered (1.2 million tareas out of 6.2 million according to the agricultural census of 1971). Of this amount, only 6,5\% was actually distributed to settlers ${ }^{90}$. This result can be consedered a striking failure, especially as one knows that this is by far the cheapest means to provide land for reform. One can safely conclude that there must be some collusion between the commission and the usufructuaries, all belonging to the vital forces backing the present government. And another factor is evident: much of the land surrendered is of such a bad quality that it is not apt for smallholder agriculture. As long as there are still large farms in the hand of individuals ${ }^{91}$, either military or civil, all other, possibly successful, measures of land reform can only distract the view from the fact that the central objective of land reform, i.e. to distribute state property, has not been achieved. In this line of reasoning, 23.8 million $\$$ spent from 1972-76 to obtain land on the basis of other laws might be considered waste of public funds ${ }^{92}$, but not so in terms of Dominican politics.

b) Law No. 282 which stipulates that all uncultivated land ("tierra baldía") should be passed to the state. Nearly as much as state-owned land has been obtained through this law (practically every week, there are short notes in this respect in the press). This is not astonishing because this normally constitutes a very profitable transaction for the former landowner. According to the law, $10 \%$ of the purchase price should be paid cash and the rest in state bonds. But this does not necessarily reflect what actually happens: some availed themselves of this opportunity and thus cleared off a substantial debt with the Banco Agricola ${ }^{93}$. This law produces the most questionable effect that poor people are settled on poor soils ${ }^{94}$. Consequently, this means low productivity and a life not much better than that they had "enjoyed" before.

c) Law No. 314 which defines what are latifundia in the Dominican Republic: the tolerable limits are 1,500 tareas for first class soils up to 45,000 for seventh class soils. 1,1 million tareas were obtained from 1972-76, but a member of the commission admits that terratenientes simply subdivided their farm amongst their family members, and the problem was solved". A law which defines "el latifundio" but not "el latifundista", proves largely useless ${ }^{96}$. It is estimated that this legal evasion of the law concerned about 2,3 million tareas ${ }^{97}$. On the other hand, the government services to handle this law are not yet sufficiently equipped to elaborate reliable and comprehensive soil classifications.

d) Law No. 289 on the resolution of lease-hold contracts, i.e. if the farm does not exceed 300 tareas, the lease-holder is offered an option by the law to buy it with government assistance. The intention of this measure is very noble: to

\footnotetext{
90 Diagnóstico Institucional. ., p. 14: El Caribe, March 27, 1976: Afirma Gobierno posee tierras no ha

91 “Las mejores tierras del sur, propiedad del Estado, están ocupadas por terratenientes privilegiados"... (Listín Diario, Nov. 4, 1974: Cree inoperante comisión tierras).

92 Listín Diario, April 13, 1976: Informa gobierno invierte 23 millones compra tierras.

93 Allusion to this practice is made by Mario Alvarez, Reforma Agraria, IV, El Caribe, April 9, 1976.

94 Carlos Dore y Cabral, Comisión para las leyes agrarias o para las tierras baldías? El Nacional, July 7, 1974.

95 Listín Diario, April 13, 1976, op. cit. (note 92).

96 Carlos Dore y Cabral, Y las 1,039,300 definidas como latifundio? El Nacional, July 4, 1974.

97 Diagnóstico y Estrategia del Desarrollo Agropecuario 1976-1986, op. cit., p. 24; and a comment in the press on this aspect of the report: Listín Diario, Dec. 3, 1975: Sostienen crece latifundio R. D.
} 
solve the precarious situation of many thousands of peasants entirely dependent on the good will of an onmipotent big landowner. But this law aroused the latter's strong and sustained resistance. They do not hesitate "to solve the question" by simply evicting by force the lease-holders or others living at a place on the basis of some tacit agreement ${ }^{98}$. So instead of solving a problem, more problems are created. This law, difficult to apply in a most complex rural environment of established social relations, certainly offers the least positive record of all instruments of the "Código Agrario". Very few cases are really decided upon by the commission ${ }^{99}$. There are even cases that members of the commission are said to have exercised pressure on peasants to leave their plots ${ }^{\mathbf{1 0 0}}$.

e) Law No. 290 providing that all rice farms exceeding 500 tareas and irrigated by state-financed canals be transferred to the state. Miraculously, up to 1975, about $60 \%$ of the target surface has been passed to the IAD ${ }^{101}$. This relatively positive result is the more astonishing if one takes into consideration that rice is the basic food-stuff in the country and that demand has always exceeded the domestically based offer. Rice production, under these conditions, would constitute a most profitable focus of private agrobusiness. The key to this result must be found in the most advantageous provisions for compensation: $25 \%$ in cash, $75 \%$ in bonds, shares of state-owned companies or state-owned real estate, situated especially in or near towns like Santo Domingo or Santiago. The general assumption is that the latter kind of compensation has been preferred ${ }^{102}$, leading to considerable speculative profits. There is also some reason to believe that government, in its desire to push at least one sector of land reform through, has been extremely generous and broadminded in granting compensations for rice farms. And zealous officials contributed their part to get things running, i.e. they calculated handsome indemnifications to the detriment of the state ${ }^{103}$. Mention has already been made of the IAD rice farms, organized on a basis of either individual or collective property, which enjoy Balaguer's special attention and financial generosity.

f) Law No. 436: Whereas all previously examined laws are part of the "Código Agrario" of 1972, this law was promulgated in 1964 already. It stipulates that one fourth of those lands developed by state-financed projects like dams, canals and other irrigation infrastructure have to be transferred free to the state. This law, though of minor importance as to the total area grasped, is easy to enforce because the revalorization of the three quarters the landowner preserves is so enormous that he gladly welcomes any government initiative in this sense $\mathrm{s}^{\mathbf{1 0 4}}$.

\footnotetext{
98 See the following examples: El Nacional, June 17, 1974: Acusan terratenientes de despojo terrenos; El Sol, July 11, 1975: Tribunal tierras verá caso labriego y terrateniente.

99 Moíses Blanco Genao, a leftist political leader, in: Ahora, No. 647, April 5, 1976, p. 19; on a contested case: Listín Diario, June 14, 1974: Sofisticada aplicación de una ley agraria; ibid., June 18, 1974: Ni sofisma, ni torpeza, ni demagogia.

100 Listín Diario, Oct. 11, 1974: Acusa comisión de ineficiente.

101 Diagnóstico Institucional . ., op. cit., p. 13.

102 Ibid., p. 11. After completion of this paper, I came across an article essentially focussing on an analysis of Law 290: Isis Duarte, República Dominicana, Reformas agrarias como forma de dominación social, in: Servicio Europeo de Universitarios Latinoamericanos (Bruxelles), Vol. 6, No. 51, 1974, pp. 7-35.

103 Mario Alvarez, La Reforma Agraria, I, El Caribe, April 6, 1976.

104 Reference to this law is made in: Dorner et al., op. cit., p. 32.
} 
This panorama of agrarian reform laws offered some insight into the reality of law implementation in the Dominican Republic. Agrarian reform is not so much a question of the rigorous enforcement of legal provisions, but more an arrangement of "do ut des" in which no partner risks to loose his face. This aspect of perhaps not in all cases amicable, but always profitable exchange under the aegis of a specific social culture will be a central element in the general assessment of the Dominican agrarian reform effort to be undertaken in the following chapter. Just one more interesting aspect should be added: Laws are dead letters if there is no public pressure to enforce them. Towards the end of 1974, hundreds of landless agricultural workers invaded private farms in various provinces of the country. They were discontented with the slow pace of agrarian reform implementation and decided to take it into their own hands. The fact as such is remarkable, because peasants are not reputed to be well organized. In this case, it seems that leaders of the "Movimiento Agrario Reformista", belonging to the governing Partido Reformista, were the driving forces behind the scene ${ }^{105}$. Members of the police and armed forces apprehended the invaders and transported them to their regional jails ${ }^{106}$. No active resistance or injuries were reported. Ministers and generals condemned the invasions in the name of public order and the principle of private property ${ }^{107}$. In the Senate, the invasions were considered "a volcano of social intranquility", and some senators expressed their dissatisfaction with the implementation of agrarian reform laws ${ }^{108}$. No public word from Balaguer. . Many months later, he felt obliged to react, and he did it in a more than commensurate manner: in an Easter pastoral letter, the bishop of Higüey (where is situated the cathedral of La Altagracia, a national sanctuary), Msgr. Hugo Eduardo Polanco Brito, depicted the extremely unjust distribution of land in the eastern province of El Seibo. He did not confine himself to such general considerations, but made special mention of six landowners who possessed 57,000 tareas, and he asked Balguer to seize at least $10 \%$ of this land for the benefit of 400 landless peasants ${ }^{109}$. As this would be insufficient for so many people, El Nacional, the afternoon newspaper, formulated the suggestion that the state should buy all the 57,000 tareas ${ }^{110}$. And Balaguer, in a supreme act of paternalism, in fact ordered the purchase of all these lands ${ }^{111}$. Startled by the president's reaction, other great landowners immediately gave in and offered part of their holdings ${ }^{112}$.

Without risking to overinterpret this special case, it seems that it is less the literal and complete application of the law that counts in agrarian reform in the Dominican Republic (Balaguer commanded much more than the laws demand) but the outcome of a multitude of ad hoc decisions (e.g. taken by the "Comisión para la Aplicación de las Leyes Agrarias") designed not to jeopardize the fragile equilibrium between the political forces in the society, be they complementary and/or antagonistic. This question is the subject of the concluding chapter.

105 El Caribe, Oct. 3, 1974: Agitadores políticos fomentan ocupaciones ilegales de tierras; ibid., Oct. 16, 1974: Acusan grupo reformista de incitar invasíon tierras.

106 Listín Diario, Oct. 10, 1974: Apresan La Vega 667 campesinos invaden tierras; El Caribe, Jan. 23, 1975: Continúan presos 500 campesinos.

107 El Caribe, Oct. 16, 1974: Secretario de Agricultura condena invasión terrenos; Listín Diario, Oct. 12, 1974: Director de IAD condena acción invadir terrenos; El Caribe, Oct. 16, 1974: General exhorta a los campesinos.

108 Listín Diario, Oct. 16, 1974: Plantean en Senado invasión de tierras.

109 El Caribe, April 8, 1976: Prelado sugiere compra tierras.

110 April 8, 1976: Incompleta sugerencia.

111 Listín Diario, April 10, 1976: Jefe de Estado dispone comprar 57 mil tareas.

112 Ibid., April 14, 1976: Ofrecen a gobierno terrenos en el Este. 


\section{The socio-political determinants of land reform}

"Each country has defined its agrarian reform in its own terms, and the method to carry it out, if it is to achieve success, must be peculiarly designed by each community ${ }^{113}$." This is true, but a further question must be raised: Do the political forces of a country really intend to achieve what can be termed a "success"? It is all too obvious that in the political process of land reform more important considerations of a paramount social order play an outstanding role. At least in the Dominican Republic, the issue has mobilized all sectors of the society, and it is instructive to learn more about their position vis-à-vis land reform. Before trying this, we have to attempt to strike a balance of the performance of the land reform programme realized since $1962^{114}$ :

a) The process is extremely slow: If all 350,000 landless labourers are to profit from this plan, it will take about 150 years (just 30,000 have been settled in 15 years). One can safely assume that the growing conscientization of peasants will not tolerate this enormous lapse of time.

b) Although land reform is so often emphasized as the top priority programme by the governing party and President Joaquín Balaguer, the administrative bodies to execute it are not given the adequate resources; they do not enjoy any privileged position compared to other government institutions.

c) Land reform does not touch the vast monoculture sugar lands either owned by the state, a Dominican family or an American multinational corporation. It is this sacrosanct sector which determines the country's export economy (dependence on the US import quota) and prevents the diversification of a possibly more inland orientated agriculture.

d) Land reform has by no means been in a position to solve the problem of minifundios which do not offer a decent life for a normal family. On the contrary, the programme has added more small subsistence plots on poor soils ceded by terratenientes. In addition, the state's technical services including the Instituto Agrario Dominicano are not sufficiently equipped to give new settlers the necessary assistance.

e) The programme has not decisively diminished the concentration of land in the hands of few people. The latter have availed themselves of all loop-holes offered by the laws and of their bargaining power to be used in the negotiations with the "Comisión para la Aplicación de las Leyes Agrarias".

f) Land reform has been paternalistic, even rather suffocating (see the collective rice farms where soldiers protect the fields in harvest time), and it has not contributed to the emergence of a liberated, self-confident peasantry able to launch its own organizations (leagues, co-operatives, etc.).

A disappointing balance for many ${ }^{115}$, especially the political opposition in the country ${ }^{116}$. But the social and political set-up of the country is too complex to allow definite conclusions as to who are the protagonists and who are the enemies of land reform. Much of the stagnation in Latin America is imputed to what is

\footnotetext{
113 Thomas Mathews, The agrarian reform in Cuba and Puerto Rico, Revista de Ciencias Sociales (Puerto Rico), IV, 1, 1960 (pp. 107-123), pp. 109/110.

114 See a similar list in Victor L. Cedeño, La cuestión agraria, Santo Domingo 1975, pp. 31-34.

115 Certainly not much has changed since José Ramón Enrique Cordero Michel was killed in the unsuccessful invasion of 1959; he left the notes published under the title "Datos sobre la reforma agraria en la República Dominicana" in: Caribbean Studies, Vol. II, No. 1, April 1962, pp. 23-33.

116 See José I. Cuello, Siete años de reformismo, Santo Domingo 1973, pp. 32-35.
} 
called "the oligarchy"116a. This might apply to many countries of the hemisphere, but not quite to the Dominican Republic. There is not much left of a great national bourgeoisie of Spanish origin, founded on large land-holdings as its central power basis. The demise of a sugar aristocracy in colonial times, the Haitian occupation and Trujillo's dictatorship produced a social composition relatively differentiated ${ }^{117}$. Of course, there is a small elite, but their fortunes come from different sources: rum or tobacco, cattle, industrial enterprises, commerce, liberal professions. "What strikes one as perhaps the most interesting aspect of the Dominican oligarchy is that it is not, as is often pictured, a monolithic group steadfastly opposed to democracy and reform in any fashion ${ }^{118}$." The present government has a most diversified power basis. Balaguer is externally supported by the United States and internally, in the first instance by the military, and the industrialists, merchants and landowners ${ }^{119}$. For the armed forces, he is the personification of the Trujillo regime in a new mould, and as even the higher ranks generally stem from the lower strata of society ${ }^{120}$ (like Trujillo himself), they eagerly support Balaguer's agrarian reform. They are able to take strong action against important landowners and they are reported to be especially dynamic members of the "Comision". In the sixties, one of the IAD directors was a general, and there is a presidential decree that the IAD should have a military co-director "to imprint the zeal, the diligence and the discipline of a career military indispensable for the effective functioning of the Institute 121 ". Without the armed forces, the outcome of the agrarian reform effort would certainly be even more negligible. But, strange to say, the military themselves constitute an important obstacle to the general implementation of the respective laws. Meanwhile, they have occupied a considerable portion of the state-owned land and have thus acquired an essential attribute of the upper classes or of what they perceive being the upper classes. They stick to that, and this stubbornness makes that the recovery of state land is such a protracted and wearisome enterprise.

André Corten offers a classification of the Dominican oligarchy particularly suited to explain the social background of land reform. He distinguishes three main groups ${ }^{122}: 1$. The great foreign capital sugar corporations with which are associated the "latifundistas", acting as cattle growers and timber merchants; 2. The great merchants of the import-export sector, but also devoting part of their resources to the first-stage elaboration of agricultural produce like tobacco, cacao and coffee; 3. The liberal professions and the political personnel in the largest sense; they invest part of their income in agriculture, if their farms are not prebends, either granted or usurped. Groups 1 and 3 are especially relevant for the context we are dealing with. It is illustrative that Corten does not offer a predominant place to the large landowners, he sees them as a correlate to foreign sugar interests. Both are indeed complementary: About half of the Gulf \& Western land is actually reserve land for cane growing and normally used for cattle-breeding. So, foreign interests are strongly linked up with national cattle growers. One expres-

116a james L. Payne, The oligarchy muddle, World Politics, XX (3), April 1968, pp. 439-453.

117 The classical work is Juan Bosch, Composición social dominicana, Santo Domingo 1970.

118 Howard Wiarda, The Dominican Republic, Nation in Transition, London 1969, p. 104.

119 Confirmed by Eduardo Latorre, Política Dominicana Contemporánea, Santo Domingo 1975 , p. 303.

120 Howard Wiarda, Dictatorship and Development, The methods of control in Trujillo's Dominican Republic, Gainesville 21970 , p. 49.

121 Decree No. 2459 of 1972, reproduced partially in: Estudios Sociales, No. 20, 1972, p. 249.

122 André Corten, Anatomie de l'oligarchie dominicaine, Cultures et Développement, Vol. I, No. 4, 1968 (pp. 801-842), p. 827. 
sion of this strong link, impossible to crack by government, is the fact that, from 1960-1971, the percentage of pasture in the country's land use increased from $38,4 \%$ to $53,7 \%$ (see Table 1 ). This movement was realized parallel to the implementation of land reform and constituted one means to circumvent the law, e.g. for rice farmers (law 290). Of course, cattle growing is extensive farming accompanied with low productivity. Though pastures are included into Law 314 (latifundia), we learned that the yield of this law, due to its relatively easy evasion by partition among family members, is particularly low.

To solve part of this problem, government took a bold step and introduced in February 1974, a bill stipulating the following: All soils of categories 1 to 3, i.e. apt for agriculture but presently used for pasture shall be passed to the IAD if they exceed 500 tareas. There was provision to exempt larger cattle farms, but those should be especially developed and modernized (this is the case of dynamic Puerto Ricans having moved in from the smaller neighbour island). This bill aroused a storm of protest with those concerned, and this did have some impact on Congress and Government ${ }^{123}$. The bill was delayed and not yet brought in again in the following legislative period 1974-78. It is significant that in the hearings relative to this bill, the IAD director and a member of the "Comision para la Aplicación de las Leyes Agrarias" introduced proposals tending to concede larger areas to be retained by cattle-breeders ${ }^{124}$. They considered the measure much too harsh and did not show any inclination to identify themselves with it. This incidence refers to Corten's group No. 3, and it is indeed known in the country that politicians and higher civil servants are not dissociated from landed interests. Either through family ties, relations of patronage or very personal interests (to possess a stretch of land is a vital aspiration in any Dominican), these people cannot be considered disinterested and uncorruptable. Beside the officers of the armed forces, there are also former or actual civil servants who call a large farm their own ${ }^{125}$. Consequently, even some of Balaguer's advisors in land reform are not infrequently accused to sabotage the reform ${ }^{126}$. One generally very perceptive critic of land reform dares draw a picture which borders on adulation: "Amidst this disgusting environment, there are the landless peasant, and the President of the Republic, the last one sometimes practically alone, occasionally ill-advised ${ }^{127}$."

Balaguer is an honourable man, but he is not outside and above politics, he represents the apex of a specific socio-political system which will be called, with Wiarda, the "corporate-patrimonialist state"128. The Dominican experience of land reform quite well fits into the characteristics of this empirically deduced model. Without delving too much into the historical roots of political behaviour in Latin America, we have to do with "a hierarchically and vertically segmented structure of class and caste stratifications, of social rank orders, functional corporations, estates, juridical groupings and 'intereses'... a rigid yet adaptable

123 A good documentation on this issue is: Carlos Dore y Cabral, Interpretación del proyecto de ley sobre tierras ganaderas, Colección Debate Núm. 5, Santo Domingo 1974; See also the article of the same author: El proyecto de ley Ganadera (esbozo de interpretación), in: Impacto Socialista, Año I, Núm. I, Jul. 1974, pp. 18-21.

124 Dore, Interpretación. . .., p. 34

125 Corten, op. cit., pp. 825/826.

126 El Caribe, May 5, 1976: Afirma sectores tratan bloquear reforma agraria.

127 Mario Alvarez, La Reforma Agraria, I, El Caribe, April 6, 1976.

128 Howard J. Wiarda, Toward a framework for the study of political change in the iberic-latin tradition: the corporative model, World Politics, XXV, 2, 1973, pp. 206-235. 
scheme whose component parts are tied to and derive legitimacy from the authority of the central state or its leader"129. This is a monistic structure where all component parts are required to maintain the "natural" order and keep peace. The head of state acts as a family head, strong, benevolent, authoritarian, functioning as the regulator between the diverse groups, interests and layers of society. Though there are perhaps less "caudillos" and "hacendados" than in the past, the patron-client relationship ${ }^{130}$ prevails dressed up in modern forms. Behind this façade of legalism and constitutionalism "political issues are dealt with more through the process of elite integration and the granting of access to the spoils and privileges that accrue with acceptance into the system, rather than through program enactment and implementation" ${ }^{131}$. This is especially relevant for the case of land reform where a new social group, the hitherto landless rural mass, is assimilated into the system, but within the framework of the ruling norms and under the tutelage of the established ruling groups, the often conjured up oligarchy. The system as such proves relatively adaptive to pressures of "modernization", but as the basic rules of the game are preserved, the final outcome of a land redistribution programme will be, by necessity, limited. "Agrarian reform... has become more an instrument of social control than of social change ${ }^{132}$."

A glance at the outcome of land reform in the Dominican Republic testifies to the ingenuity of the corporate state to guarantee, to a very considerable extent, peace and equilibrium within a conservative society. It becomes evident that land reform is not a zero-sum game but that all actors - should one say miraculously or logically? - derive benefits from a supposedly disruptive measure:

- the great landowners for giving up part of their land, mostly of poor quality, receive very advantageous compensations (in cash or kind, state bonds, and formerly state-owned real estate in the urban agglomerations), in sum: they virtually have preserved or even increased their assets ${ }^{133}$.

- for the most direct beneficiaries of land reform, the new settlers (usually called "parceleros"), a dream has come true: they were given a piece of land. "The owner and his family may still be in poor health, undernourished and in debt but much more often than not his outlook is better than the individual without land ${ }^{\mathbf{1 3 4}}$." The prestige and security of land is underligned in a common expression of satisfaction: "Ahora tengo donde trabajar ${ }^{135}$." Of course, land reform has been a very slow process, but many thousands of landless agricultural labourers entertain the hope that once they will also benefit from the president's kindness. The only value which counts, in their perception, is land as such, much less land as a basis for rationally cultivated and marketable agricultural crops.

- the state as the initiator of land reform is also one of its main beneficiaries: Instead of fleecing the rich, those in power have succeeded in retaining the latter's loyalty, even creating new bonds of gratitude. But this is a very

129 Ibid., pp. 210/211.

130 It is particularly strong on the local level. See Malcolm T. Walker, Politics and the power structure. A rural community in the Dominican Republic, New York/London 1972, p. 144.

131 Wiarda, Toward a framework. ., p. 223

132 Ibid., p. 224. The title of this paper is drawn from the statement.

133 El Caribe, Aug. 5, 1974: Reforma no afecta terratenientes, afirma ha cambiado sus activos (referring to a conference given by Bernardo Vega, one of the best economists of the country).

134 Westbrook, op. cit. (note 37), p. 306.

135 Ibid., p. 307. 
fragile relationship, and the co-operation of the "oligarchy" is strictly limited (see Ley ganadera). The political elite respects these limits, thus absorbing possible restiveness at this level ${ }^{136}$. Loyalty from a large section of the peasantry and continued support from the upper classes constitute a sound basis for a political regime of the autocratic-patrimonialist order.

In such a system, "the bureaucracy serves to dispense the available goods, favors,

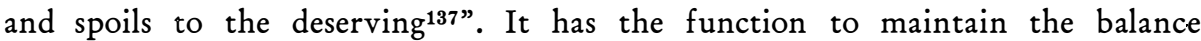
between the various interests and to guarantee political solidarity. The civil service is thus the backbone of the patrimonial state and completely embedded into its value system. It has no chance nor is it given the means to develop its own value system, perhaps according to more rational and secular lines. Moreover, the civil service is itself an object of the corporate state spoils system where friends, party followers and former oppositionists are put on the public payroll138. For such a bureaucracy, programme and law ${ }^{139}$ implementation can only be of a secondary order.

\footnotetext{
136 This tendency not to scare anyone of the established "intereses" is very evident in an IAD advertisement which reads as follows (Listín Diario, May 31, 1975): "La tierra para quien la trabaja desde siempre. Esa es la consigna. Pero el proceso de una reforma agraria es lento. Mucho más si es un proceso. que se cumple fielmente dentro de los marcos de la ley y de la paz. Justicia para los campesinos que trabajan la tierra y que no la poseen. Pero justicia, también, para quienes la han poseído. Este es el dilema que se resuelve en el campo desde hace nueve años. Este es el más importante jalón de justicia social en la obra del Presidente Balaguer."

137 Wiarda, Toward a framework. .., p. 222.

138 In the Dominican Republic, there is also a separate President's payroll covering more than 1.000 people who at best render petty services to the state.

$139 \mathrm{H}$. J. Wiarda, Law and political development in Latin America: Toward a framework for analysis, in: Idem (ed.), Politics and Social Change in Latin America: The Distinct Tradition, Amherst 1974, pp. 199-229. See also Ernest Feder, Counterreform, in: R. Stavenhagen (ed.), Agrarian problems and peasant movements in Latin America, Garden City 1970 (pp. 173-223), pp. 190/191.
} 


\title{
Social Control instead of Social Change: The Administration of Land Reform in the Dominican Republic
}

\author{
By Hans F. Illy
}

It is nearly a commonplace now that land tenure constitutes a significant dimension of the pattern of political power in many countries. Consequently, land reforms should be analysed much more as a political process than as a merely technical one. Or more precisely, the following question has to be answered: Which are the political and social factors that have determined the poor outcome of the reform effort? As the public administration system is the main implementing agency of land reform, an emphasis should be laid on its scope of action in relation to the political actors who set the general policy.

After having given some relevant data on land reform in the Dominican Republic and its origin and orientation through outside pressure in the sixties, the study focusses on the administrative set-up and implementation process of "reforma agraria" going into the details of how far specific laws are put into practice.

The overall picture drawn from this analysis is the following:

1. The reform is extremely slow and has by no means contributed to solve the problems of "minifundios" and landless agricultural labourers.

2. There is a marked discrepancy between offical declarations proffered by President Balaguer and inadequate resources given to the executing agency, the Instituto Agrario Dominicano.

3. The programme has not decisively diminished the concentration of land in the hands of few people. Either large sectors are excluded from the reform (especially the sugar lands) or the "terratenientes" have used their bargaining power to turn the laws into mechanisms to strengthen their position (e.g. via most favourable compensations).

4. The civil service has no proper freedom of action. It is completely subdued to the political will of those in power and is embedded into their value system.

5. The Dominican Republic offers a most traditional example of a political system of the corporative-patrimonial type. Patron-client relationships prevail behind a façade of legalism and constitutionalism. Political issues such as land reform are not allowed to jeopardize vested interests of the ruling groups. The latter are prepared to make certain concessions to absorb social pressure from below but impose strict limits: Land reform becomes more an instrument of social control than of social change.

\section{Labour migration and structural heterogeneity in West Africa}

\section{By Alfred Schmidt}

The interpretation of labour migration as a mechanism which connects different structural elements of capitalist societies at the periphery implies a criticism of some common views: Migration is said to reallocate human resources efficiently, to modernize "backward" subsistence economies, to eliminate regional differences of development, and to indicate social change which brings about an "achieving 